Passive dyeing bacterial cellulose: Results of a contact and low heat method

\author{
Jennifer Harmon
}

\title{
University of Wyoming
}

Literature Review. Dyes are soluble chemicals that contain chromophores (Bomgardner, 2018). The dyes compounds can be natural or synthetic, though synthetics are more commonly used. Dyeing cotton is a more water and heat intensive process than dyeing polyester (Bomgardner, 2018). It takes about $200 \mathrm{~L}$ of water to produce $1 \mathrm{~kg}$ of cotton and leaves behind dyes and chemicals in the wastewater (Bomgardner, 2018). A majority of paper products are dyed at the preparation, or pulp stage (Drzewińska. 2008). This dye can be basic, direct or fiber reactive.

Cotton, the most popular cellulosic fiber in the world, contains few impurities (Gordon \& Hsieh, 2007). Cotton fibers are used to make the majority of textile and apparel goods (Gordon $\&$ Hsieh, 2007). However, problems remain in dyeing cotton. Bacterial cellulose (BC), however, is produced by acetic-acid bacterium and produces a biodegradable, vegetable leather-like product (Iguchi et. al., 2000).BC exhibits increased tensile strength and water absorbing capability (El-Saied et. al., 2008). BC also lacks hemicellulose and lignin and is composed of micro-cellulose fibrils extruded by acetobacter xylinum (Iguchi et. al., 2000). Lacking hemicellulose and lignin, the micro-fibrils interact through hydrogen bonds. These interactions result in a highly crystalline, absorbent fiber-web (Hsieh et. al., 2008). Drying methods intensely impact the material, even at room temperature, potentially resulting in a stiff, somewhat brittle textile (Harmon et. al., 2017). This indicates that gentle heat will be needed when dyeing. To this point, few studies have explored the coloration potential of bacterial cellulose. To investigate this potential, the following study investigated $\mathrm{BC}$ dye uptake from a colored substrate at low heat. Experiment Methodology. To test dyeing bacterial cellulose, ATCC A. xylinus strain 53524 was cultivated in modified Molasses Mannitol (MSM) media. The bacteria were grown for one week and transferred to medium sterilized at 121 degrees $\mathrm{C}$ for 25 minutes. Containers were incubated at 32 degrees $\mathrm{C}$ for 21 days. Then, mats were harvested and placed in a $1 \% \mathrm{NaOH}$ soak for 24 hours at room temperature. The mats were treated with a $4 \%$ glycerol, $1 \%$ germaben solution at room temperature for 24 hours. The mats were rinsed and drained. Mats were placed on blue, red and yellow cotton fabric and incubated. After 24 hours, no color transfer occurred. Samples were rehydrated, placed on colored paper and incubated.

Results. As can be seen in the pictures below, all colors were absorbed by the bacterial cellulose.

Blue Front

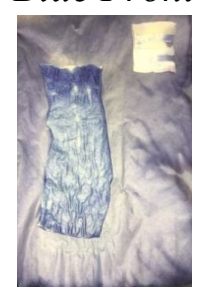

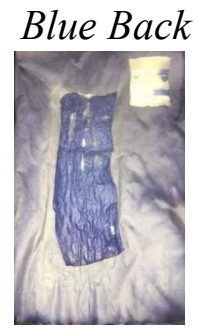
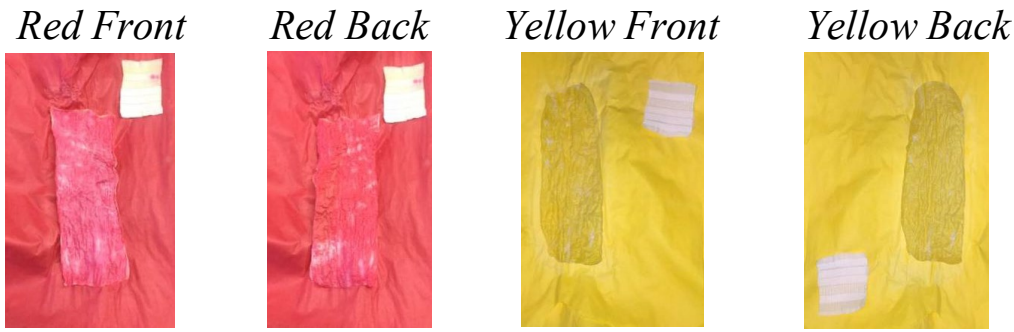

Page 1 of 3

Published under a Creative Commons Attribution License (https://creativecommons.org/licenses/by/4.0/), which permits unrestricted use, distribution, and reproduction in any medium, provided the original work is properly cited.

ITAA Proceedings, \#76 - https: / /itaaonline.org 
Visual Analysis. The back of the samples, which had direct contact with the colored paper, absorbed more color than the front of samples for both the blue and red conditions. There was uneven contact with the surface, leading to pockets of white, uncolored material. Colorfastness. AATCC Test Method 8 Colorfastness to Crocking: Crockmeter Method was used to test color fastness to wet and dry crocking. Change in color as a result of crocking was evaluated with AATCC Gray Scale for Color Change using .5 rating gradations. Samples tested were 1.5 by 5 inches and were crock tested with plain weave cotton print cloth. Two evaluators analyzed each sample in a light box using the daylight setting. The average color change rating for the dry crocked blue sample was 4.25, red sample 5.00 and the yellow sample 5.00. These results indicate little to no color change from dry rubbing the surface of the sample. Next, the wet crocking color change was tested. The average color change rating for wet crocked blue sample was 3.25, red sample 3.75 and the yellow sample 4.5. These results indicate moderate to little color change from wet rubbing the surface of the sample. AATCC Test Method 16.3

Colorfastness to Light: Xenon-Arc was used to measure colorfastness to continuous light exposure in a custom built light exposure device modeled after Australian test method 2001.4.21: Determination of colourfastness to light using an artificial light source. Samples were mounted in the circular lamp and exposed to continuous light for 1 week. These samples were then compared to unexposed samples by two evaluators in a light box using the daylight setting. The average color change rating for the light exposed blue sample was 1.75, red sample 3.75 and the yellow sample 3.25. These results indicate significant to moderate color change from continuous light exposure for 1 week.

Conclusion. These preliminary results indicate that this material can be dyed and display moderate to good colorfastness using a low temperature (approximately 89.6 degrees F) passive method with little additional water. These results indicate that dyeing performance of the material will likely be excellent with synthetic dyes. Future researchers interested in exploring this method of coloration, potentially with colored cellulose waste, should consider having two layers of paper to cover the cellulose and weighting the top. This would increase dye uptake and uniformity while reducing un-dyed areas.

Acknowledgement. This project was possible with a University of Wyoming AES; NIFA grant.

\section{References.}

Bomgardner, M. M. (2018, July 15). These new textile dyeing methods could make fashion more sustainable. Chemical and Engineering News, 96(29).

Drzewińska, E. (2008). The influence of pulp on the colour of dyed papers. Fibres\& Textiles in Eastern Europe, 16(1),103-107.

El-Saied, H., El-Diwany, A. I., Basta, A. H., Atwa, N. A., \& El-Ghwas, D. E. (2008). Production and characterization of economical bacterial cellulose. Bioresources, 3(4), 1196-1217.

Gordon, S. \&Hsieh, Y. L. (2007). Introduction. In S. Gordon \& Y.L. Hsieh (Eds.), Cotton: Science and technology (xv-xx). Cambridge, England: Woodhead Publishing.

Published under a Creative Commons Attribution License (https://creativecommons.org/licenses/by/4.0/), which permits unrestricted use, distribution, and reproduction in any medium, provided the original work is properly cited.

ITAA Proceedings, \#76 - https: / /itaaonline.org 
Harmon, J., Fairbourn, L. and Thibault, N. (2017). Comfort and aesthetic properties of bacterial cellulose for textile applications. Presented atInternational Textile and Apparel Association 2017 conference, St. Petersburg, FL.

Hsieh, Y., Yano, H., Nogi, M., \& Eichhorn, S. J. (2008). An estimation of the Young's modulus of bacterial cellulose filaments. Cellulose, 15(4), 507-513.

Iguchi, M., Yamanaka, S. \&Budhiono, A. Journal of Materials Science (2000) 35: 261.

Page 3 of 3

(c) 2019 The author(s). Published under a Creative Commons Attribution License

(https://creativecommons.org/licenses/by/4.0/), which permits unrestricted use, distribution, and reproduction in any medium, provided the original work is properly cited.

ITAA Proceedings, \#76 - https://itaaonline.org 